\title{
Environmental Temperature Units
}

National Cancer Institute

\section{Source}

National Cancer Institute. Environmental Temperature Units. NCI Thesaurus. Code C90381.

The units of measure that are used to express the temperature of the surroundings. 